Article

\title{
Design and Operation of Decentralized Reservoirs in Urban Drainage Systems
}

\author{
Eui Hoon Lee and Joong Hoon Kim * \\ School of Civil, Environmental and Architectural Engineering, Korea University, 02841 Seoul, Korea; \\ hydrohydro@naver.com \\ * Correspondence: jaykim@korea.ac.kr; Tel.: +82-02-3290-3316
}

Academic Editor: Peter J. Coombes

Received: 21 February 2017; Accepted: 29 March 2017; Published: 31 March 2017

\begin{abstract}
Poor drainage of urban storm water can lead to urban inundation which presents a risk to people and property. Previous research has presented various measures to prevent and reduce urban flooding and these measures can be classified into costly but effective structural measures, and economical but less effective non-structural measures. This study suggests a new approach to reduce urban flooding by combining structural and non-structural measures in a target watershed in Seoul, South Korea. Inlet design modification in a detention reservoir (Decentralized Reservoir, DR) is examined in conjunction with combined inlet/outlet management for the DR. Monitoring nodes used to control DR inlet/outlet operations are selected by locating the first flooding node, maximum flooding node and DR inlet node. This new approach demonstrates outstanding flood volume reduction for historical flooding events that occurred in Seoul during 2010 and 2011. Flood volumes during the 2010 event using the combined inlet/outlet operation in the DR were between $1656 \mathrm{~m}^{3}$ and $1815 \mathrm{~m}^{3}$ compared to a flood volume of $6617 \mathrm{~m}^{3}$ using current DR operation. Finally, the suggested operating level for the DR based on the best hydraulic section, system resilience index, and local regulations is $1.2 \mathrm{~m}$.
\end{abstract}

Keywords: urban flooding; decentralized reservoirs; inlet/outlet operation; inlet design

\section{Introduction}

The frequency of extreme rainfall events has increased with recent environmental change. Furthermore, the extent of impervious surfaces in urban areas has risen rapidly. Consequently, the incidence of urban inundation has increased markedly. To mitigate the risk of urban inundation, many solutions for preventing urban flooding have been suggested [1]. These solutions can be categorized into structural and non-structural measures. Structural measures refer to infrastructure changes including the construction of new drainage facilities and rehabilitation or replacement of sewer networks. Non-structural measures refer to technological or behavioral innovations which do not require significant infrastructure investment, including flood prediction, improved rainfall forecasting, and revised operating procedures for drainage facilities. Non-structural measures are significantly cheaper to apply as compared to structural measures however, they are also somewhat limited in their ability to prevent or reduce flooding. For example, improving the operation of drainage facilities can do little to reduce flooding if the facility was designed to withstand a 30-year maximum rainfall event and a 100-year maximum rainfall event occurs.

Various structural and non-structural measures have been proposed for preventing and reducing urban inundation (Table 1). Research regarding structural measures to reduce inundation include investigating the optimal capacity and location of detention reservoirs [2-5], and analysis/design of various facilities such as rainwater tanks, rainwater storages and trenches [6-13], and the use of pump stations in conjunction with detention reservoirs [14] while research into non-structural measures 
has included the real time operation of reservoirs and urban drainage systems [1,5-24], continuous simulation for assessment and sustainable management [25-27], and flooding forecasting/best management practices [28-30]. Research on combined measures has also contained the management of urban drainage systems with structural and non-structural measures such as analyzing fallacy of floods, mitigation of flood hazards and adaptation strategies of semi-structural and non-structural measures [31-35].

Table 1. Classification of the measures employed by previous studies to reduce inundation in urban drainage systems.

\begin{tabular}{|c|c|c|c|}
\hline Structural Measures & Non-Structural Measures & Combined Measures & $\begin{array}{c}\text { Combined Measures in } \\
\text { Decentralized } \\
\text { Reservoir }\end{array}$ \\
\hline $\begin{array}{l}\text { AL-Hamati et al. (2010) [3] } \\
\text { Chill and Mays (2013) [4] } \\
\text { Chung et al. (2008) [2] } \\
\text { Coombes (2009) [6] } \\
\text { Coombes (2015) [9] } \\
\text { Coombes and Downes (2015) [10] } \\
\text { Graber (2010) [14] } \\
\text { Matos Silva and Costa (2016) [13] } \\
\text { Lucas and Coombes (2009) [7] } \\
\text { Tao et al. (2014) [5] } \\
\text { Van der Sterren and Rahman } \\
\text { (2015) [11] }\end{array}$ & $\begin{array}{l}\text { Bruen and Yang (2006) [28] } \\
\text { Cembrano et al. (2004) [16] } \\
\text { Fiorelli et al. (2013) [21] } \\
\text { Fuchs and Beeneken (2005) [17] } \\
\text { Galelli et al. (2012) [20] } \\
\text { Hsu et al. (2000) [15] } \\
\text { Hsu et al. (2013) [22] } \\
\text { Kuczera and Coombes (2002) [25] } \\
\text { Kundzewicz (2002) [26] } \\
\text { Lee et al. (2016) [1] } \\
\text { Martin et al. (2007) [29] } \\
\text { Simonovic (2002) [27] } \\
\text { Smith et al. (2007) [30] } \\
\text { Pleau et al. (2005) [18] } \\
\text { Raimondi and Becciu (2015) [23] } \\
\text { Tellez-Castro et al. (2016) [24] } \\
\text { Vanrolleghem et al. (2005) [19] }\end{array}$ & $\begin{array}{l}\text { Gruntfest (2000) [34] } \\
\text { Marsalek et al. (1993) [32] } \\
\text { Pielke (1999) [33] } \\
\text { Poussin et al. (2012) [35] } \\
\text { Thampapillai and Musgrave } \\
\text { (1985) [31] }\end{array}$ & This study \\
\hline
\end{tabular}

Various studies include research on structural, non-structural and combined measures for reducing urban inundation. This study focus on combined measure for detention reservoir in urban drainage system such as alternative inlet design and inlet/outlet operation of detention reservoir. The operation of detention reservoirs as a non-structural measure has a structural limitation such as small capacity of drainage pumps because the design of drainage pumps in detention reservoir were not designed considering inflow to detention reservoir in Korea. For overcoming this limitation, inlet and outlet operation in detention reservoir are required to obtain additional space in detention reservoir. A detention reservoir has no ability to mitigate urban inundation if it is filled with received water. Hence, this study examines a new operation method for inlet and outlet controls in a detention reservoir (Decentralized Reservoir, DR) combined with a new inlet design for the DR. This study consists of four parts: (1) selection of the monitoring nodes used to operate the inlets and outlets in the DR; (2) an investigation of inlet design and replacement of the inlet weir with an inlet gate in the DR; (3) an investigation of the impacts of the new inlet/outlet operating procedures in the DR; and (4) a determination of the operating level in the DR using a system resilience index and the best hydraulic section for urban drainage systems.

\section{Methodology}

\subsection{Monitoring Node Selection}

Careful selection of monitoring nodes is essential to effectively operate inlet gates and outlet drainage pumps in the DR. Almost all detention reservoirs in the urban drainage systems of South Korea have inlets that are designed as weirs. Consequently, managed inlet operation is impossible because the inlet weir has a fixed height and all flow over the weir enters the detention reservoir. Managed inlet operation is made possible by replacing inlet weirs with gates. The effects of managed inlet gate operations, which are controlled by the level of the monitoring nodes, are compared to the current inlet weirs in DR. 
The DR outlet is operated based on monitoring nodes within the urban drainage system and the effects of managed outlet operation were verified in an earlier study [1]. The inlet gate is open and outlet drainage pumps are not operated when water levels at the monitoring nodes are high. Conversely, the inlet gate is closed and outlet drainage pumps are operated when water levels at the monitoring nodes are low. The effects of combined operation, when the inlet gate and outlet drainage pumps are both operated according to the level of the monitoring nodes, is compared with the current operation in DR. The operating levels in the DR are determined by the resilience index and best hydraulic section in the urban drainage system.

A flowchart for this study is shown in Figure 1. The first part of this study is the selection of monitoring nodes for inlet/outlet operations in DR. Two methods were used to select the monitoring nodes. Firstly, the first flooding node was detected using a rainfall-runoff simulation because the first flooding node is one of the most susceptible nodes for inundation in an urban drainage system. To maintain a safe urban drainage system, identification of the first flooding node is critical for effective DR operation. Secondly, the maximum flooding node was identified. This node is important because it illustrates the most at risk region of the urban drainage system.

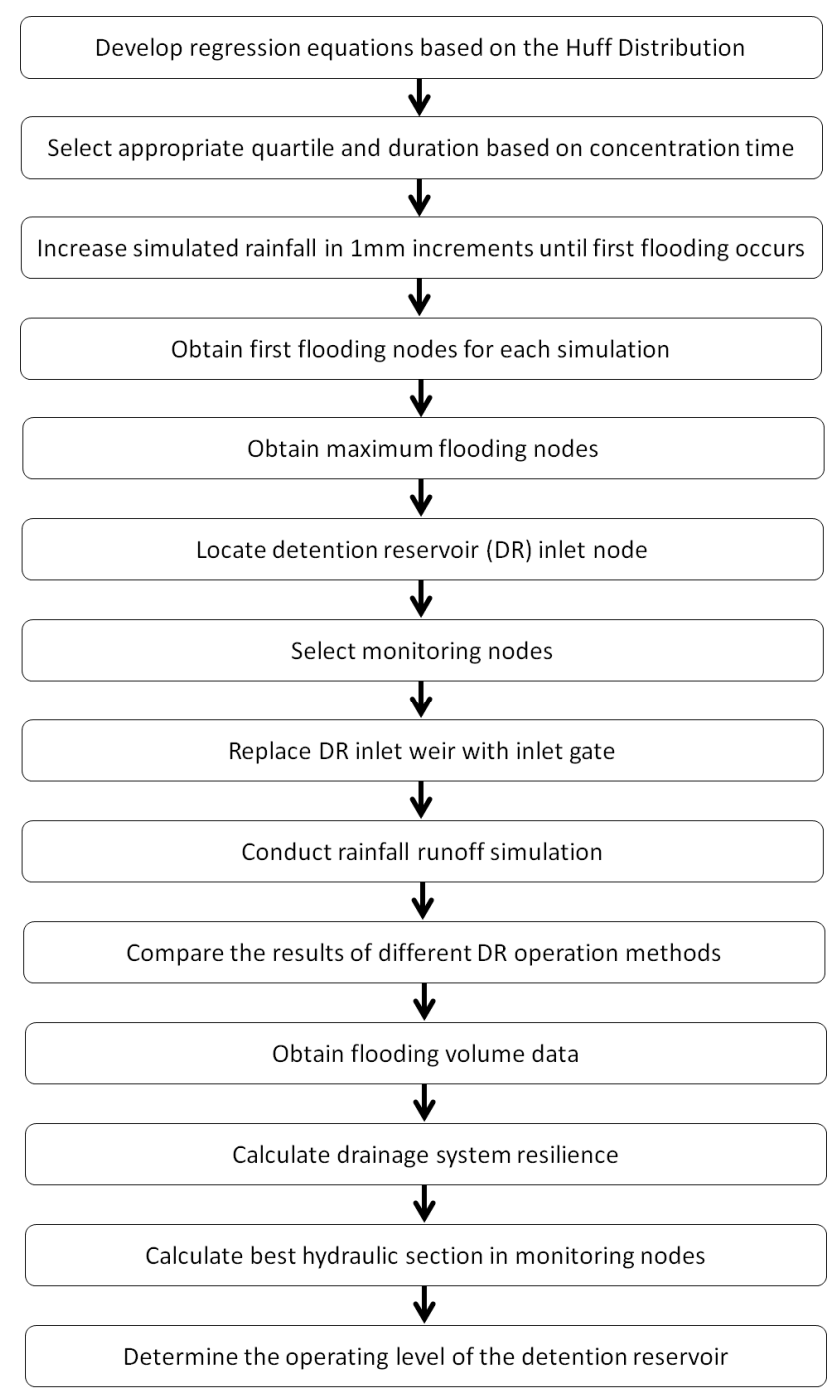

Figure 1. Flowchart for new detention reservoir (DR) operation and inlet design.

Thorough evaluation of monitoring nodes is required because the design frequency of conduits in urban drainage systems frequently differ. For example, the design frequency of branch conduits tends 
to be smaller than that of main conduits which means that flooding can easily occur in nodes between branch conduits. However, these nodes should not be selected for monitoring purposes because they do not represent the entire drainage system. Hence, rainfall-runoff simulations should be conducted to facilitate the selection of monitoring nodes. Synthetic rainfall data by Huff (1967) [36] were used in this study because the DR in the target watershed was designed using the Huff distribution.

Selection of first flooding nodes starts with the determination of rainfall distribution. Then, several durations are selected considering the time of concentration in target watershed. The initial value of total rainfall volume is $1 \mathrm{~mm}$ and the total rainfall is distributed by selected distribution. The distributed rainfall is applied to rainfall-runoff model and flooding results are obtained. If flooding occurs, the flooding node is selected as the first flooding node and the flooding volume is also checked. If no flooding occurs, the total rainfall volume is assumed $2 \mathrm{~mm}$ with $1 \mathrm{~mm}$ increment. This process is repeated until first flooding nodes are obtained.

Selection of maximum flooding nodes also begins with the determination of rainfall distribution. Various frequencies and durations are selected and generated by selected distribution. The distributed rainfall is applied to rainfall-runoff model and flooding results are obtained. The maximum flooding node among flooding nodes is examined in each rainfall data, respectively. If it is hard to select the monitoring node because maximum flooding nodes is different from each other, historical rainfall data are applied to rainfall-runoff model for obtaining the maximum flooding node.

\subsection{Generation of Synthetic Rainfall Data}

Synthetic rainfall data are necessary for monitoring node selection and to determine the operating level of the DR. The design of almost all hydraulic facilities in South Korea is based on the Huff distribution [36]. This distribution consists of four quartiles and the difference between each quartile represents the timing of peak rainfall. For example, the first quartile has the peak value of rainfall in the first quarter of rainfall duration. The regression equations for the first, second, third, and fourth quartiles of the Huff distribution for Seoul, South Korea are shown in Equations (1)-(4), respectively (Korea Precipitation Frequency Data Server) [37],

$$
\begin{gathered}
y=29.289 x^{6}-95.64 x^{5}+119.7 x^{4}-70.768 x^{3}+18.176 x^{2}+0.2426 x-0.0007 \\
y=-38.505 x^{6}+118.93 x^{5}-132.67 x^{4}+60.815 x^{3}+8.3001 x^{2}+0.7296 x+0.0005 \\
y=37.835 x^{6}-106.21 x^{5}+105.18 x^{4}-44.549 x^{3}+9.1084 x^{2}-0.3603 x+0.0005 \\
y=-25.498 x^{6}+63.755 x^{5}-57.196 x^{4}+22.882 x^{3}-3.4377 x^{2}+0.4955 x-0.0002
\end{gathered}
$$

where $y$ represents the cumulative rainfall ratio and $x$ is the cumulative time ratio in total duration. In Seoul, the third-quartile of the Huff distribution was determined to be an appropriate rainfall distribution based on an examination of rainfall events and calculating discharge in the urban watershed (Yoon et al., 2013) [38].

\subsection{Alteration of Inlet Type in the DR}

In South Korea, almost all DR in urban drainage systems have an inlet weir and the design frequency of the weir is generally smaller than the design frequency of the DR itself. The present operation in the DR is based on outlet management using drainage pumps. Reserved water in the DR is released when one of two conditions is satisfied; firstly, water reaches the limit level of the DR, and secondly, operators of the DR determine that the rainfall event has concluded. The capacity of the drainage pumps in the DR is determined at the design phase of the reservoir using the designed drainage time of the DR. The general structure of the DR is shown in Figure 2. Inlet management of the DR using a fixed inlet weir is impossible and the storage capacity of the DR decreases during continuous rainfall. The DR cannot reserve capacity for follow-up inflow because a DR with a fixed inlet weir receives initial low frequency inflow during continuous rainfall events. To address this 
issue, the inlet weir is replaced with an inlet gate, which is operated based on the water level at the monitoring and inlet nodes.

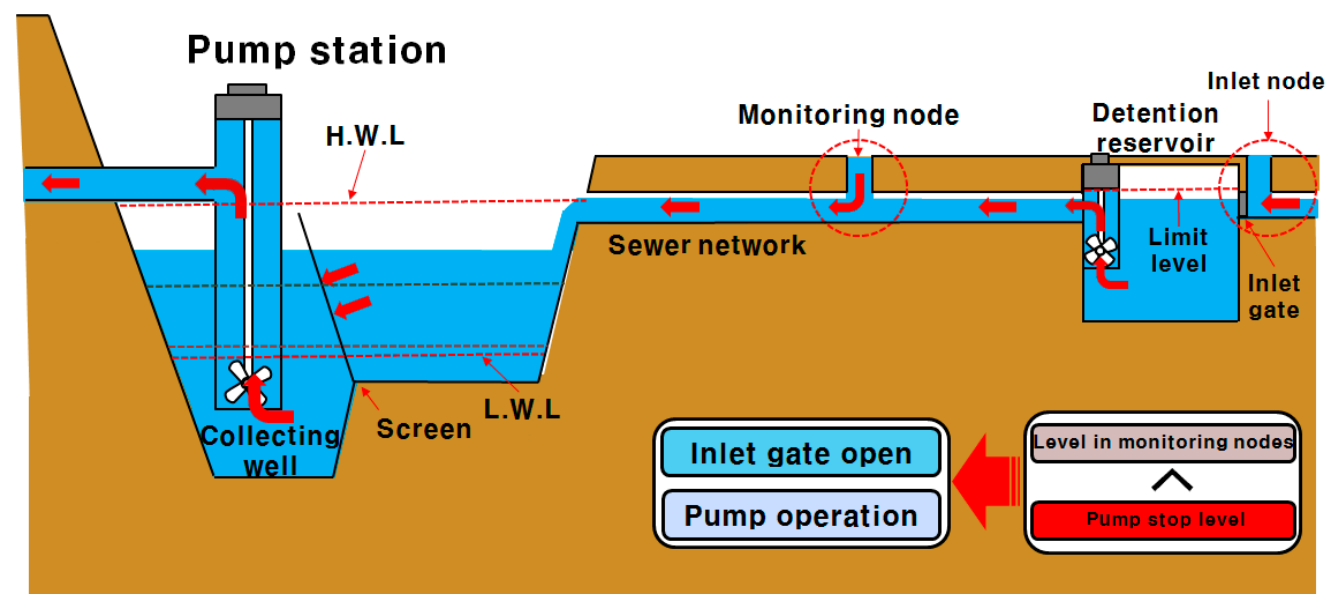

Figure 2. Structure of a DR in an urban drainage system.

\subsection{Determination of DR Operational Level}

The resilience index of an urban drainage system can be defined as the ability of the system to recover from a failure such as the malfunction of drainage facilities or inundation [1]. Resilience index is defined using Equation (5),

$$
u(T)_{i}=\max \left(0, \quad 1-\frac{F_{i}}{R_{d} \times A_{u}}\right) \quad\left(R_{d}=\sum_{i-t_{c}}^{i} R_{i}\right)
$$

where $u(T)_{i}$ is the performance evaluation function at time $i, F_{i}$ is the flooding volume $\left(\mathrm{m}^{3}\right)$ at time $i, t_{c}$ is time of concentration ( $\mathrm{min}$ ) in the target watershed [39], $R_{i}$ is the rainfall at the present time (i), $R_{d}$ is accumulated rainfall during the present time (i) and $i-t c\left(10^{-3} \mathrm{~m}\right)$, and $A_{u}$ is the unit area ( $1 \mathrm{ha}=10^{-4} \mathrm{~m}^{2}=0.01 \mathrm{~km}^{2}$ ). The time of concentration is a concept to be used in hydrology and it is the estimated time while rainfall in the farthest region of watershed flows to watershed outlet. Equation (5) cannot be calculated if flooding occurs when there is no rainfall because the denominator of Equation (5) is 0 if there is no rainfall. The negative value of Equation (5) does not exist because the value of rainfall, flooding volume, and area is not the negative value. The unit area instead of the catchment area is used because the big value of the catmint area could enormously reduce failure depth. A high performance evaluation value indicates that the drainage system has a high ability to recover after flooding or system failure. The resilience of the urban drainage system by performance evaluation function per minute is calculated as shown in Equation (6),

$$
R_{s}=\frac{1}{T_{n}} \int_{T_{0}}^{T_{n}} u(T) d T
$$

where $R_{s}$ is the resilience of the urban drainage system in target watershed, $T_{0}$ is the start time of the rainfall event and $T_{n}$ is the end time of the rainfall event. In this study, 48 rainfall datasets with four frequencies (30, 50, 80, and 100 years) and three durations (30, 60, and $90 \mathrm{~min}$ ) from the Huff Distribution [36] are used. The operational level of the DR is calculated at the point where the system begins to flood. 


\section{Target Area and Rainfall Runoff Model}

Seoul, South Korea is traversed by the Han River (Figure 3). One of tributaries of the Han River is the Anyang Stream, which also has several tributaries including the Dorim Stream. The Dorim Stream has two detention reservoirs (Daerim detention reservoir and Gwanak detention reservoir), ten pump stations (Guro 1, Guro 2, Guro 3, Guro 4, Mullae, Dorim 1, Daerim 2, Daerim 3, Sinlim, and Sinlim 5), and two tributaries (Daebang Stream and Bongchun Stream). The Daerim detention reservoir within the urban drainage system of the Daerim 3 pump station was selected for this study. The drainage system of the Daerim 3 pump station is adjacent to the drainage system of Daerim 2 pump station. In the 1990s, two drainage areas including Daerim 3 and Daerim 2 pump stations were combined into one drainage area and Daerim 3 pump station drained all the flow in target watershed. The drainage area was divided into two drainage areas and Daerim 2 pump station was established because it is an area where flooding is frequent. The drainage area of Daerim 3 pump station including Daerim detention reservoir is 248.5 ha. The Daerim detention reservoir was constructed upstream of the drainage network in 2009 [17].

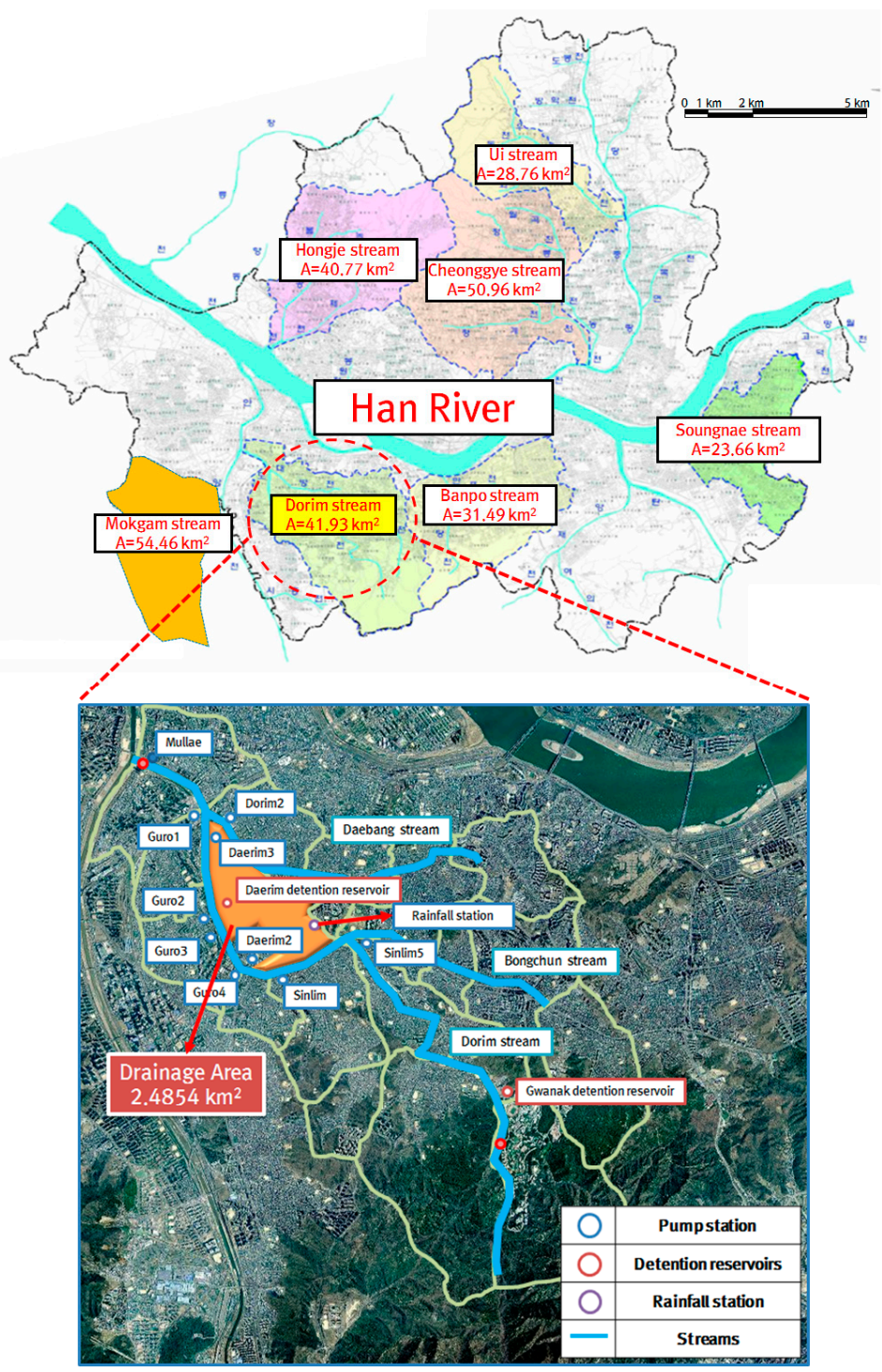

Figure 3. Location and features of the target watershed in Seoul (from Google Earth Imagery @ Google Inc., 2015). 
In the target watershed, flooding occurred twice, in 2010 and 2011, after the DR was completed $[40,41]$. The selected rainfall-runoff model is the Storm Water Management Model (SWMM), developed by the US Environmental Protection Agency [42]. The Seoul Metropolitan Government supplied urban drainage system information and Geographic Information System (GIS) data for Seoul. The sewer network for the Daerim 3 pump station is shown in Figure 4.

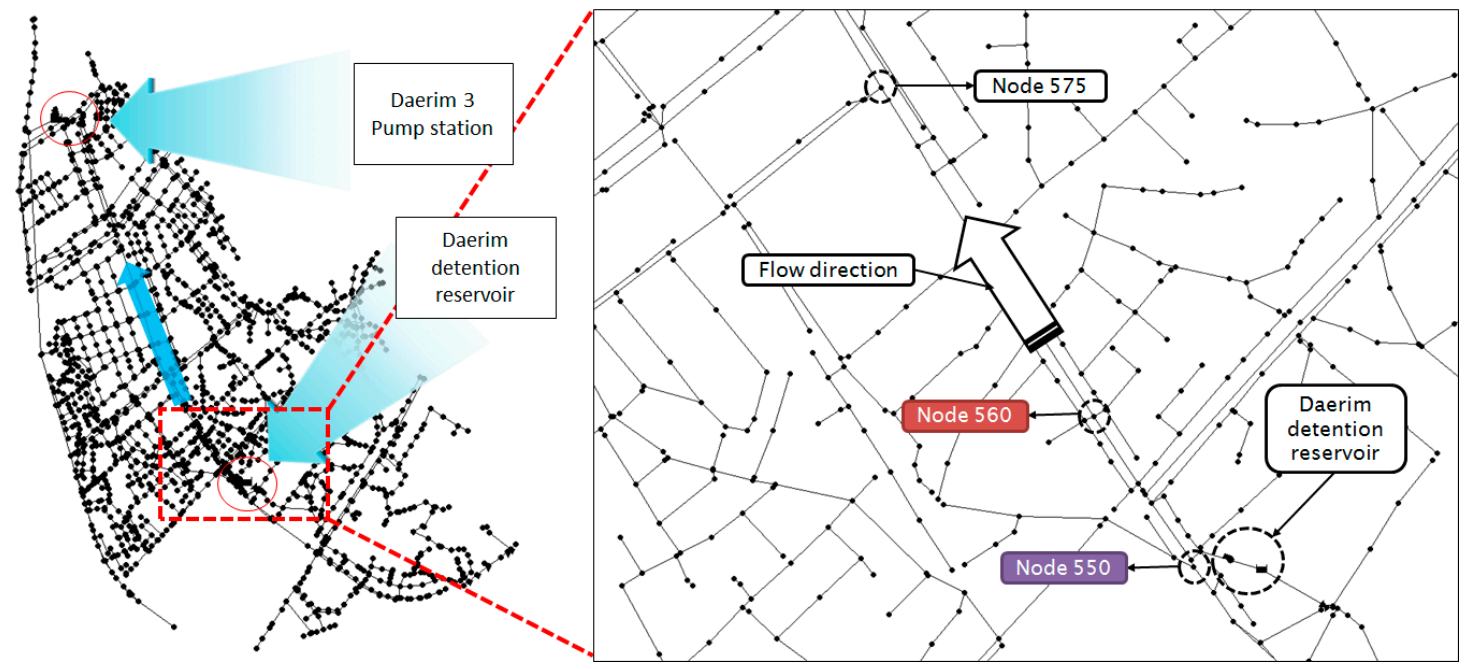

Figure 4. Location of the first and maximum flooding nodes in the main conduits.

The Daerim DR was designed with a 20-year frequency and 210 min of critical duration. It receives water from the target drainage system through an inlet weir with a five-year frequency. The total capacity of Daerim DR is $2447 \mathrm{~m}^{3}$ and the reservoir discharges through two drainage pumps $(22 \mathrm{~kW}$, $9 \mathrm{~m}^{3} / \mathrm{min}$ ) without gravitational drainage. The entire depth and freeboard of the DR is $3.2 \mathrm{~m}$ and $1.0 \mathrm{~m}$, and the width and height of the inlet weir is $2 \mathrm{~m}$ and $0.4 \mathrm{~m}$, respectively. Inflows over the inlet weir go to the DR through a rectangular inflow conduit with $2 \mathrm{~m}$ width and $1.5 \mathrm{~m}$ depth (Yeongdeungpo-Gu, 2007) [43].

\section{Application Results and Discussion}

To select monitoring nodes for the DR, we examined the first flooding nodes in the target watershed. Considering the time of concentration in the target watershed (30 $\mathrm{min})$, three durations of 30,60 , and 90 min were selected for the rainfall-runoff simulation. To be a candidate for monitoring, nodes needed to be located between the main conduits and have a subcatchment area greater than $0.12 \mathrm{~km}^{2}$. First flooding nodes located in main conduits of the target watershed are shown in Figure 4. The first flooding node for 30- and 60-min durations is node 560, when the total rainfall is $79 \mathrm{~mm}$ and $104 \mathrm{~mm}$, respectively. The first flooding node for the 90 -min duration simulation is node 575 , with total rainfall of $154 \mathrm{~mm}$. Considering the time of concentration in the target watershed, node 560 was selected as a monitoring node.

To identify the maximum flooding nodes, nine rainfall datasets (frequency: 30, 50 and 100 years; duration: 30, 60 and $90 \mathrm{~min}$ ) were generated using the Huff distribution [36]. However, these results were inconclusive, with nine different maximum flooding nodes identified by the nine simulations. Consequently, historical rainfall data, from 23 September 2010 and 27 July 2011, when flooding occurred in the watershed, were used to identify the maximum flooding nodes. Based on the historical data, node 550 was found to be the maximum flooding node and was selected as a monitoring node. To summarize, nodes 550 and 560, and the inlet node of the Daerim DR were selected as monitoring nodes. 
The depth of the monitoring nodes is $1.5 \mathrm{~m}$. For the combined inlet/outlet operation of the detention reservoir, operating levels between $0.8 \mathrm{~m}$ (approximately half of node depth) and $1.5 \mathrm{~m}$ (node depth) were selected because the simulated operating levels from $0.0 \mathrm{~m}$ to $0.7 \mathrm{~m}$ showed similar or worse results as compared to the current operation of the DR. Low operating levels mean that detention reservoir receives water and reserved water (not discharge) when water levels in the sewer network are low.

The depth of the monitoring nodes means the pipe diameter. Small diameter is chosen as the depth of the monitoring nodes if the diameter of the inlet pipe is different from it of the outlet pipe. If the depth of the monitoring nodes is different from each other, each depth is applied to the range from $0.0 \mathrm{D}$ to $1.0 \mathrm{D}$. For example, $1.5 \mathrm{~m}$ is same with $1.0 \mathrm{D}$ if the depth of the monitoring node is $1.5 \mathrm{~m}$ and $1.2 \mathrm{~m}$ is same with $1.0 \mathrm{D}$ if the depth of the monitoring node is $1.2 \mathrm{~m}$.

The inlet weir was replaced with and inlet gate in the DR and the impact of combined inlet/outlet operation with operating levels from $0.8 \mathrm{~m}$ to $1.5 \mathrm{~m}$ were assessed. Figure 5 shows the comparison between the current operation, outlet operation, and combined inlet/outlet operation in the DR. Figure 5a shows the results of the three operations in the 2010 flooding event and Figure $5 \mathrm{~b}$ shows the results of the three operations in the 2011 event.
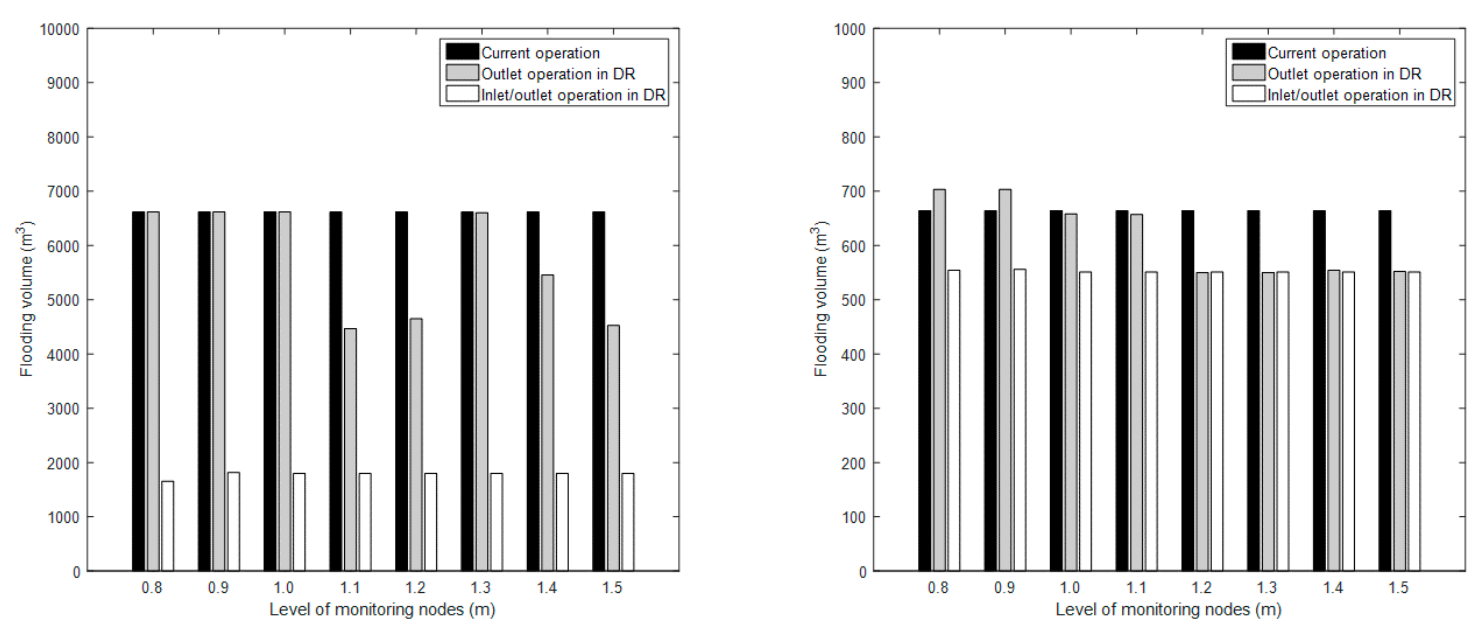

Figure 5. Flooding volumes compared to the level of monitoring nodes for three DR operation methods: current operation (black); outlet operation (grey); and combined inlet/outlet operation (white).

Daerim detention reservoir was settled in 2009 because the flooding in 2001 occurs in the location of Daerim detention reservoir. The settlement of Daerim detention reservoir cannot prevent flooding in 2010 and 2011 events because the elevation of the location is very low compared with surrounded areas. Low elevation in urban drainage is one of main reasons about urban flooding. The design and operation is very important to prevent flooding in target watershed.

For the 2010 event, the result of current operation is $6617 \mathrm{~m}^{3}$ regardless of the level of monitoring nodes because current operation has no relation with the level of monitoring nodes. The results of outlet operation in the DR are distributed from $4466 \mathrm{~m}^{3}$ to $6617 \mathrm{~m}^{3}$. There are no differences between the current operation and outlet operation in the DR when the water level of the monitoring nodes is low, that is, when drainage pumps in the DR were stopped. The flooding volume using combined inlet/outlet operation in the DR range between 1656 and $1815 \mathrm{~m}^{3}$. The results of combined inlet/outlet operation in the DR show the best performance of the three operating methods for all levels of monitoring nodes.

For the 2011 event, flood volume using current operation is $664 \mathrm{~m}^{3}$ for all monitoring node levels. Results for outlet operation in the DR are between $552 \mathrm{~m}^{3}$ and $703 \mathrm{~m}^{3}$. Poor results are apparent for low water levels at monitoring nodes between $0.8 \mathrm{~m}$ and $0.9 \mathrm{~m}$. Results are similar to the current operation when the water levels at monitoring nodes are between $1.0 \mathrm{~m}$ and $1.1 \mathrm{~m}$. When the monitoring node 
water levels are high $(1.2 \mathrm{~m}, 1.3 \mathrm{~m}, 1.4 \mathrm{~m}$, and $1.5 \mathrm{~m})$, outlet operation shows better results as compared to current operation. The flooding volume for inlet/outlet operation in the DR is distributed from $551 \mathrm{~m}^{3}$ to $556 \mathrm{~m}^{3}$. The results of combined inlet/outlet operation in the DR show the best performance of the three operations. It is notable that combined inlet/outlet operation results are superior for all monitoring node levels. Combined inlet/outlet operation shows the smallest variance of flooding volume and total flooding volume for both the 2010 and 2011 events. These results imply that that combined inlet/outlet operations of the DR can substantially reduce flooding volume.

Outlet operation performs better than current operation except when the water level at the monitoring nodes is low. Outlet operation in the DR is limited by the capacity of the drainage pumps $\left(0.3 \mathrm{~m}^{3} / \mathrm{s}\right)$. The simulated maximum inflow to the DR was approximately $1.33 \mathrm{~m}^{3} / \mathrm{s}$ when rainfall frequency distribution was 100 years. This means that operators cannot empty or fill the DR. Inlet/outlet operation shows outstanding performance compared to both current operation and outlet operation. The results of system resilience based on Huff distribution synthetic rainfall data are shown in Table 2.

Table 2. System resilience based on Huff distribution synthetic rainfall data.

\begin{tabular}{cccccccccc}
\hline \multirow{2}{*}{$\begin{array}{c}\text { Frequency } \\
\text { (Year) }\end{array}$} & $\begin{array}{c}\text { Duration } \\
\text { (h) }\end{array}$ & \multicolumn{8}{c}{ Level of Monitoring Nodes (m) } \\
\cline { 3 - 10 } & 1 & 0.976811 & 0.976621 & 0.975778 & 0.976686 & 0.976172 & 0.976251 & 0.976352 & 0.976259 \\
\multirow{3}{*}{30} & 2 & 0.964705 & 0.964773 & 0.965201 & 0.96519 & 0.965415 & 0.965086 & 0.965402 & 0.965646 \\
& 3 & 0.973304 & 0.973507 & 0.973062 & 0.973691 & 0.973854 & 0.973992 & 0.97392 & 0.973962 \\
\hline \multirow{3}{*}{50} & 1 & 0.963912 & 0.963607 & 0.963292 & 0.963387 & 0.96368 & 0.963705 & 0.963652 & 0.963675 \\
& 2 & 0.944443 & 0.944335 & 0.944485 & 0.944406 & 0.945028 & 0.9442 & 0.94444 & 0.944805 \\
& 3 & 0.959146 & 0.958863 & 0.959394 & 0.958907 & 0.959789 & 0.959963 & 0.959656 & 0.959653 \\
\hline \multirow{3}{*}{80} & 1 & 0.947714 & 0.948491 & 0.948231 & 0.947996 & 0.94817 & 0.947891 & 0.948163 & 0.948089 \\
& 2 & 0.924426 & 0.92451 & 0.924551 & 0.924161 & 0.92509 & 0.925087 & 0.924854 & 0.925132 \\
& 3 & 0.942119 & 0.942488 & 0.942498 & 0.942407 & 0.942104 & 0.942677 & 0.941117 & 0.942674 \\
\hline \multirow{2}{*}{100} & 1 & 0.940061 & 0.940262 & 0.938688 & 0.940016 & 0.939854 & 0.940077 & 0.940115 & 0.93989 \\
& 2 & 0.914608 & 0.914156 & 0.915503 & 0.915463 & 0.915451 & 0.915626 & 0.915527 & 0.914929 \\
& 3 & 0.93334 & 0.933331 & 0.934014 & 0.933816 & 0.934192 & 0.933979 & 0.934051 & 0.933925 \\
\hline
\end{tabular}

Values of system resilience in Table 2 are calculated by values of the performance evaluation function ranging from 0 to 1 . The system resilience of urban drainage system is 1 if there are no flood. System resilience is high in low frequency rainfall events such as 30-year and it is low in high frequency rainfall events such as 100-year. Values of system resilience in Table 2 are different from each other according to levels of monitoring nodes. For example, an average system resilience in all frequency and duration is 0.946162 when levels of monitoring nodes are $0.8 \mathrm{~m}$ and it is 0.949053 when levels of monitoring nodes are $1.5 \mathrm{~m}$. System resilience in high levels of monitoring nodes from $1.2 \mathrm{~m}$ to $1.5 \mathrm{~m}$ is stably high.

Determining the operating level in the DR is difficult because it is directly linked with urban inundation in the target watershed. In this section, the operating level in the DR was determined using a resilience index and the concept of best hydraulic section. For calculating the system resilience in the target watershed, the flooding volume is required. Performance evaluation of the target watershed using Equation (5) is calculated using the flooding volume, and system resilience is calculated using Equation (6). A total of 12 rainfall events with four frequencies (30, 50, 80, and 100 years) and three durations $(60,120$ and $180 \mathrm{~min})$ were generated using the Huff distribution for rainfall-runoff simulation. Frequencies of rainfall scenarios were all over 30 years because there was no inundation when rainfall frequency distributions under 30 years were applied to the rainfall-runoff simulations. Furthermore, durations of rainfall data are all more than one hour because there is no difference 
between DR operating methods when rainfall durations are short. The results of system resilience are shown in Table 2.

The average of total system resilience in Table 2 was 0.948891 and the average system resilience for each operating level was considered to determine the operating level in the DR. Average system resilience for each operating level and the total average system resilience are shown in Figure 6 . The average system resilience of operating levels from $1.2 \mathrm{~m}$ to $1.5 \mathrm{~m}$ is higher than the total average system resilience.

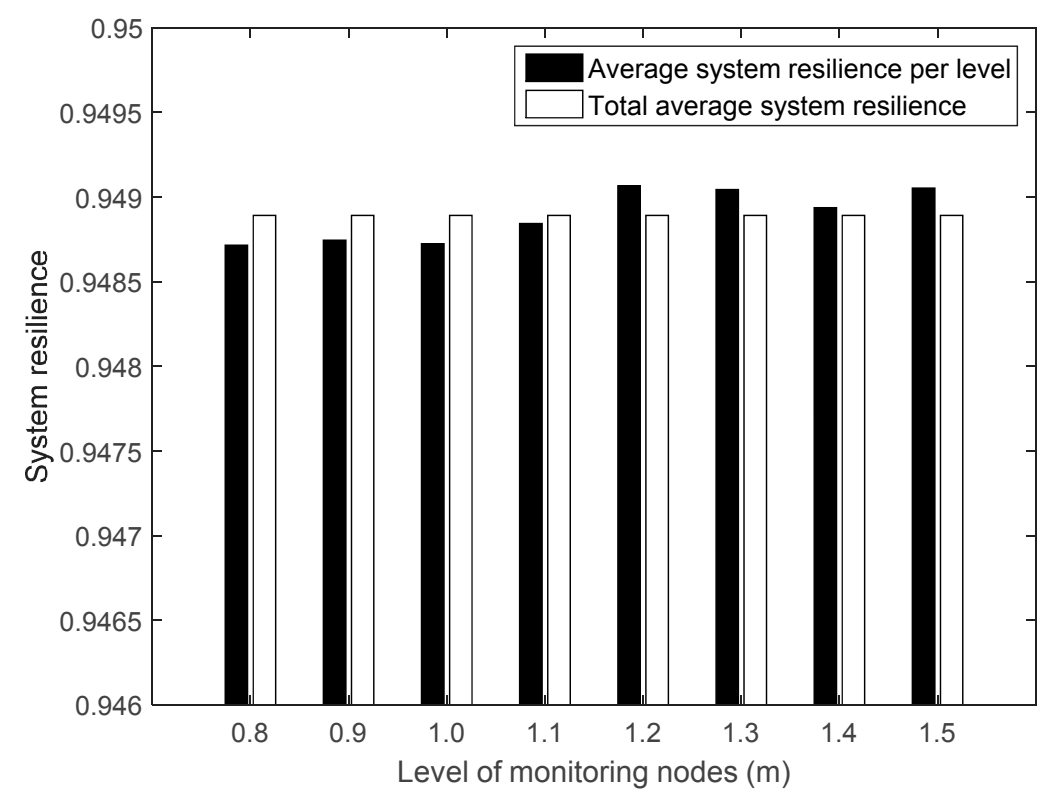

Figure 6. Comparison of average system resilience (black) and total system resilience (white) compared with monitoring node water level.

The best hydraulic section in conduits is considered. In closed conduits, water flows with gravity if it has a free water surface. The best hydraulic section in rectangular conduits cannot be calculated though the best hydraulic section in circular conduits because the velocity and flow rate in rectangular conduits linearly increase. However, the best hydraulic section in circular conduits is suggested for determination of operating level in detention reservoir because more than $80 \%$ of all conduits are circular conduits in target watershed and the majority of conduits in Korea are circular conduits. Circular conduits in urban drainage systems have different relation between discharge and velocity when whole conduit sections are filled with water compared to when partial section of conduits are filled with water. This relation can be described as a hydraulic characteristic curve. Figure 7 shows the cross section of circular conduit. Discharge area, wetted perimeter and hydraulic mean radius in conduits is calculated by Equation (7),

$$
\begin{aligned}
& A=\frac{\pi D^{2}}{4} \times \frac{\theta}{2 \pi}+\frac{D}{2} \sin \left(\frac{2 \pi-\theta}{2}\right) \times \frac{D}{2} \cos \left(\frac{2 \pi-\theta}{2}\right)=\frac{D^{2}}{8}(\theta-\sin \theta) \\
& P=\frac{D}{2} \theta, \quad R_{h}=\frac{A}{P}=\frac{D}{4}\left(\frac{\theta-\sin \theta}{\theta}\right)
\end{aligned}
$$

where $A$ is the discharge area in circular conduit $\left(\mathrm{m}^{2}\right), D$ is the diameter of conduit $(\mathrm{m}), \theta$ is the angle between the center of conduit and water surface (radian), $P$ is the wetted perimeter $(\mathrm{m})$, and $R_{h}$ is the hydraulic mean radius (m). Discharge in the conduit can be described by Manning's equation, Equation (8),

$$
Q=\frac{1}{n} A R^{2 / 3} S_{0}^{1 / 2}=\frac{1}{n}\left[\frac{D^{2}}{8}(\theta-\sin \theta)\right]\left[\frac{D}{4}\left(\frac{\theta-\sin \theta}{\theta}\right)\right]^{2 / 3} S_{0}^{1 / 2}=K \frac{D^{8 / 3}}{8 \times 4^{2 / 3}}\left[\frac{(\theta-\sin \theta)^{5 / 3}}{\theta^{2 / 3}}\right]
$$


where $Q$ is the discharge $\left(\mathrm{m}^{3} / \mathrm{s}\right), n$ is Manning's roughness coefficient, $S_{0}$ is the slope of conduit, and $K$ is the constant ratio between $S_{0}$ and $n . \theta$ is determined from 0 to $2 \pi$. If the conduit is filled with water, then the discharge of conduit can be explained as $Q_{F}$ in Equation (9).

$$
Q_{F}=K \frac{D^{8 / 3} \theta}{8 \times 4^{2 / 3}}
$$

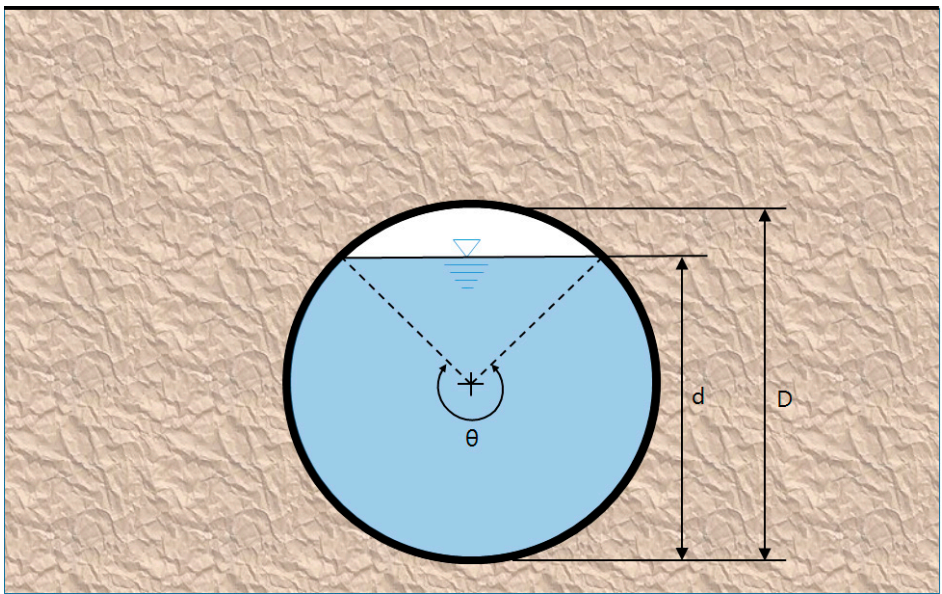

Figure 7. Schematic of uniform flow in a circular conduit.

The ratio between partial flow $Q$ and full flow $Q_{F}$ is shown in Equation (10).

$$
\frac{Q}{Q_{F}}=\frac{1}{2 \pi}\left[\frac{(\theta-\sin \theta)^{5 / 3}}{\theta^{2 / 3}}\right]
$$

Equation (8) is differentiated about $\theta$ to obtain the maximum discharge $\left(Q_{\max }\right)$ of a conduit. $Q_{\max }$ is calculated when $\theta$ is 5.28 radian $\left(\theta=303^{\circ}\right)$. The ratio of $d$ and $D$ is 0.938 when $\theta$ is $303^{\circ}$. Hence, the depth of maximum discharge in the monitoring nodes $(d)$ is $1.407 \mathrm{~m}$ because the total depth of monitoring nodes $(D)$ is $1.5 \mathrm{~m}$. The range of the ratio of $d$ and $D$ when $Q$ is larger than $Q_{\text {max }}$ is from 0.81 to 1.00 and the range of monitoring nodes is approximately from $1.2 \mathrm{~m}$ to $1.5 \mathrm{~m}$. The level of conduits also gratifies the qualification of best hydraulic section if the level of the monitoring nodes satisfies the condition of best hydraulic section.

Engineers should consider a safety factor including differences between real discharge and design discharge when they design urban drainage conduits in South Korea. Safety factors for urban drainage conduits are based on the diameter of the conduit. For example, regulations stipulate that large conduits with diameters over $1500 \mathrm{~mm}$ should have an excess capacity of between $25 \%$ and $50 \%$ (Korea Water and Wastewater Association, 2011) [44]. Safety factors in monitoring nodes range from 1.25 to 1.5. The operating level including a safety factor is from $1.0 \mathrm{~m}$ (safety factor $=1.5 \mathrm{~m} / 1.5=1.0 \mathrm{~m}$ ) to $1.2 \mathrm{~m}$ (safety factor $=1.5 \mathrm{~m} / 1.25=1.2 \mathrm{~m}$ ). The possible operating level in the DR based on the resilience index, best hydraulic section, and local regulation is shown in Table 3.

Table 3. DR operating level based on the system resilience index, best hydraulic section and local regulations.

\begin{tabular}{ccccc}
\hline Process & $\begin{array}{c}\text { System Resilience } \\
\text { Index }\end{array}$ & $\begin{array}{c}\text { Best Hydraulic } \\
\text { Section }\end{array}$ & Local Regulation & $\begin{array}{c}\text { Possible Operating } \\
\text { Level (m) }\end{array}$ \\
\hline Range of level $(\mathrm{m})$ & $1.2-1.5$ & $1.2-1.5$ & $1.0-1.2$ & 1.2 \\
\hline
\end{tabular}




\section{Conclusions}

This study suggested combined changes to inlet design and inlet/outlet operation of DR in urban drainage systems to reduce the incidence of urban inundation. This study was comprised of four steps. Firstly, monitoring nodes for operating DR inlet and outlet were selected. Secondly, the DR inlet weir was replaced with an inlet gate after an investigation of inlet design. Thirdly, the impact of a combined inlet/outlet operating procedure for the DR was investigated using the rainfall-runoff model SWMM and compared to the current operation and outlet only operation. Finally, the operating level in the DR was determined using a system resilience index and best hydraulic section for an urban drainage system in the target watershed.

Synthetic rainfall data were generated using the Huff distribution, and the most suitable quartile of synthetic rainfall data for the target watershed was selected. Rainfall durations of 30, 60, and $90 \mathrm{~min}$ were selected for a rainfall-runoff simulation to find the first flooding nodes considering the time of concentration in the target network. Total rainfall was increased in $1 \mathrm{~mm}$ increments until first flooding occurred. Node 560 was the first flooding node in 30- and 60-min duration simulations and this node was selected as a monitoring node. Maximum flooding nodes were identified using historical rainfall data. In two historical rainfall events, node 550 was the maximum flooding node; hence, this node was selected as a monitoring node. The DR inlet node was selected as the final monitoring node.

For combined inlet/outlet operation in the DR, the inlet weir was replaced with an inlet gate. The inlet gate is open and outlet drainage pumps stop when the water level of monitoring nodes is high. Conversely, the inlet gate is closed and outlet drainage pumps are operational when the water level of monitoring nodes is low. Rainfall-runoff simulations for the current operation, outlet operation, and combined inlet/outlet operation in the DR were conducted. The flooding volume of outlet operation is generally smaller than that of current operation. The exceptional cases arise based on two reasons; the frequency of applied rainfall data and reserve gradient of some sewer conduits. The frequency distributions of the 2010 and 2011 rainfall events are approximately 100 years. Extreme rainfall with a 100-year return period produces exceptional results because the maximum design frequency of urban drainage system in South Korea is 30 years. Flooding volume using the combined inlet/outlet operation is considerably smaller than the flooding volume using the current operation and outlet operation methods.

DR operating level was determined using the system resilience index and best hydraulic section. Average system resilience was higher than total average system resilience when the operating level was between $1.2 \mathrm{~m}$ and $1.5 \mathrm{~m}$. The best hydraulic section in circular conduits is when the ratio (d/D) between water level (d) and total level (D) is 0.938 . The range of water levels that produce a discharge greater than $Q_{F}$ with full flow was $1.2 \mathrm{~m}$ to $1.5 \mathrm{~m}$. Hence, the operating level of the Daerim detention reservoir was determined to be $1.2 \mathrm{~m}$, accounting for local regulations. This study highlighted the benefits of inlet/outlet operation in the DR and determined the operating level for the DR. Follow up research based on these findings is planned including the operation of multiple detention reservoirs, determination of monitoring nodes using entropy, and integrated operations between river and urban drainage systems.

Acknowledgments: This research was supported by a grant (13AWMP-B066744-01) from the Advanced Water Management Research Program funded by the Ministry of Land, Infrastructure, and Transport of the Korean government.

Author Contributions: Eui Hoon Lee carried out the survey of previous studies and wrote the draft of the manuscript. Eui Hoon Lee revised the draft to the final manuscript and simulated the inlet/outlet operation. Eui Hoon Lee and Joong Hoon Kim conceived the original idea of the proposed method.

Conflicts of Interest: The authors declare no conflict of interest.

\section{References}

1. Lee, E.H.; Lee, Y.S.; Joo, J.G.; Jung, D.; Kim, J.H. Flood Reduction in Urban Drainage Systems: Cooperative Operation of Centralized and Decentralized Reservoirs. Water 2016, 8, 469. [CrossRef] 
2. Chung, J.H.; Han, K.Y.; Kim, K.S. Optimization of detention facilities by using multi-objective genetic algorithms. J. Korea Water Resour. Assoc. 2008, 41, 1211-1218. [CrossRef]

3. AL-Hamati, A.A.N.; Ghazali, A.H.; Mohammed, T.A. Determination of storage volume required in a sub-surface stormwater detention/retention system. J. Hydrol. Environ. Res. 2010, 4, 47-53. [CrossRef]

4. Chill, J.; Mays, L.W. Determination of the optimal location for developments to minimize detention requirements. Water Resour. Manag. 2013, 27, 5089-5100.

5. Tao, T.; Wang, J.; Xin, K.; Li, S. Multi-objective optimal layout of distributed storm-water detention. Int. J. Environ. Sci. Technol. 2014, 11, 1473-1480. [CrossRef]

6. Coombes, P.J. The Use of Rainwater Tanks as a Supplement or Replacement for Onsite Stormwater Detention (OSD) in the Knox area of Victoria. In Proceedings of the H2009: 32nd Hydrology and Water Resources Symposium, Newcastle, Australia, 30 November-3 December 2009.

7. Lucas, S.A.; Coombes, P.J. The Performance of Infiltration Trenches Constructed to Manage Stormwater Runoff from an Existing Urbanised Catchment. In Proceedings of the H2009: 32nd Hydrology and Water Resources Symposium, Newcastle, Australia, 30 November-3 December 2009.

8. Lucas, S.A.; Coombes, P.J. Mains water savings and stormwater management benefits from large architecturally-designed under-floor rainwater storages. In Proceedings of the SSEE 2009: Solutions for a Sustainable Planet, Melbourne, Australia, 23-24 November 2009.

9. Coombes, P.J. Transitioning Drainage into Urban Water Cycle Management. In Proceedings of the 9th International Water Sensitive Urban Design (WSUD), Newcastle, Australia, 19-23 October 2015.

10. Coombes, P.J.; Downes, G. A decade of observations of local water cycle management at the Buderim Escape project. In Proceedings of the 36th Hydrology and Water Resources Symposium: The art and science of water, Hobart, Australia, 7-10 December 2015.

11. Van der Sterren, M.; Rahman, A. Single lot on site detention requirements in New South Wales Australia and its relation to holistic storm water management. Sustain. Water Qual. Ecol. 2015, 6, 48-56. [CrossRef]

12. Coombes, P.J.; Babister, M.; McAlister, T. Is the science and data underpinning the rational method robust for use in evolving urban catchments. In Proceedings of the 36th Hydrology and Water Resources Symposium: The art and science of water, Hobart, Australia, 7-10 December 2015.

13. Matos Silva, M.; Costa, J.P. Flood Adaptation Measures Applicable in the Design of Urban Public Spaces: Proposal for a Conceptual Framework. Water 2016, 8, 284. [CrossRef]

14. Graber, S.D. Generalized method for storm-water pumping station design. J. Hydrol. Eng. 2010, 15, 901-908. [CrossRef]

15. Hsu, M.H.; Chen, S.H.; Chang, T.J. Inundation simulation for urban drainage basin with storm sewer system. J. Hydrol. 2000, 234, 21-37. [CrossRef]

16. Cembrano, G.; Quevedo, J.; Salamero, M.; Puig, V.; Figueras, J.; Martı, J. Optimal control of urban drainage systems. A case study. Control Eng. Pract. 2004, 12, 1-9. [CrossRef]

17. Fuchs, L.; Beeneken, T. Development and implementation of a real-time control strategy for the sewer system of the city of Vienna. Water Sci. Technol. 2005, 52, 187-194. [PubMed]

18. Pleau, M.; Colas, H.; Lavallée, P.; Pelletier, G.; Bonin, R. Global optimal real-time control of the Quebec urban drainage system. Environ. Modell. Softw. 2005, 20, 401-413. [CrossRef]

19. Vanrolleghem, P.A.; Benedetti, L.; Meirlaen, J. Modelling and real-time control of the integrated urban wastewater system. Environ. Modell. Softw. 2005, 20, 427-442.

20. Galelli, S.; Goedbloed, A.; Schwanenberg, D.; van Overloop, P.J. Optimal real-time operation of multipurpose urban reservoirs: Case study in Singapore. J. Water Res. Plan. 2012, 140, 511-523. [CrossRef]

21. Fiorelli, D.; Schutz, G.; Klepiszewski, K.; Regneri, M.; Seiffert, S. Optimised real time operation of a sewer network using a multi-goal objective function. Urban Water J. 2013, 10, 342-353. [CrossRef]

22. Hsu, N.S.; Huang, C.L.; Wei, C.C. Intelligent real-time operation of a pumping station for an urban drainage system. J. Hydrol. 2013, 489, 85-97. [CrossRef]

23. Raimondi, A.; Becciu, G. On pre-filling probability of flood control detention facilities. Urban Water J. 2015, 12, 344-351. [CrossRef]

24. Tellez-Castro, D.; Quijano, N.; Mojica-Nava, E. Decentralized control for urban drainage systems via moving horizon observer. In Proceedings of the 2016 IEEE Conference, Seattle, WA, USA, 27-30 June 2016. 
25. Kuczera, G.; Coombes, P.J. Towards continuous simulation: A comparative assessment of flood performance of volume-sensitive systems. In Proceedings of the SIA 2002 Conference of Stormwater Management: Orange, New South Wales, Australia, 23-24 April 2002.

26. Kundzewicz, Z.W. Non-structural flood protection and sustainability. Water Int. 2002, 27, 3-13. [CrossRef]

27. Simonovic, S.P. Two new non-structural measures for sustainable management of floods. Water Int. 2002, 27, 38-46. [CrossRef]

28. Bruen, M.; Yang, J. Combined hydraulic and black-box models for flood forecasting in urban drainage systems. J. Hydrol. Eng. 2006, 11, 589-596. [CrossRef]

29. Martin, C.; Ruperd, Y.; Legret, M. Urban stormwater drainage management: The development of a multicriteria decision aid approach for best management practices. Eur. J. Oper. Res. 2007, 181, 338-349. [CrossRef]

30. Smith, J.A.; Baeck, M.L.; Meierdiercks, K.L.; Miller, A.J.; Krajewski, W.F. Radar rainfall estimation for flash flood forecasting in small urban watersheds. Adv. Water Resour. 2007, 30, 2087-2097. [CrossRef]

31. Thampapillai, D.J.; Musgrave, W.F. Flood damage mitigation: A review of structural and nonstructural measures and alternative decision frameworks. Water Resour. Res. 1985, 21, 411-424. [CrossRef]

32. Marsalek, J.; Barnwell, T.O.; Geiger, W.; Grottker, M.; Huber, W.C.; Saul, A.J.; Schilling, W.; Torno, H.C. Urban drainage systems: Design and operation. Water Sci. Technol. 1993, 27, 31-70.

33. Pielke, R.A. Nine fallacies of floods. Clim. Chang. 1999, 42, 413-438. [CrossRef]

34. Gruntfest, E. Nonstructural mitigation of flood hazards. In Inland Flood Hazards: Human Riparian and Aquatic Communities; Cambridge University Press: Cambridge, UK, 2000.

35. Poussin, J.K.; Bubeck, P.; Aerts, J.C.J.H.; Ward, P.J. Potential of semi-structural and non-structural adaptation strategies to reduce future flood risk: Case study for the Meuse. Nat. Hazards Earth Syst. Sci. 2012, 12, 3455. [CrossRef]

36. Huff, F.A. Time distribution of rainfall in heavy storms. Water Resour. Res. 1967, 3, 1007-1019. [CrossRef]

37. Korea Precipitation Frequency Data Server. Available online: www.k-idf.re.kr (accessed on 30 March 2017).

38. Yoon, Y.N.; Jung, J.H.; Ryu, J.H. Introduction of design flood estimation. J. Korea Water Resour. Assoc. 2013, $46,55-68$.

39. Seoul Metropolitan Government. Report on Design and Expansion of Daerim 3 Pump Station; Seoul Metropolitan Government: Seoul, Korea, 2010.

40. Ministry of Public Safety and Security. The Disaster Year Book; Ministry of Public Safety and Security: Seoul, Korea, 2010.

41. Ministry of Public Safety and Security. The Disaster Year Book; Ministry of Public Safety and Security: Seoul, Korea, 2011.

42. United States Environmental Protection Agency (USEPA). Storm Water Management Model User's Manual Version 5.0; EPA: Washington DC, USA, 2010.

43. Yeongdeungpo-Gu. Report on Design of Daerim Detention Reservoir; Yeongdeungpo-Gu: Seoul, Korea, 2007.

44. Korea Water and Wastewater Works Association. Standard on Sewer Facility; Ministry of Environment: Seoul, Korea, 2011.

(C) 2017 by the authors. Licensee MDPI, Basel, Switzerland. This article is an open access article distributed under the terms and conditions of the Creative Commons Attribution (CC BY) license (http:/ / creativecommons.org/licenses/by/4.0/). 